\title{
SIHITISE VORMIHOMONÜÜMIA - KEELEUURIJA PROBLEEM, KEELEÕPPIJA TUGI
}

\author{
Raili Pool \\ Tartu Ülikool
}

Lähivertailuja 17.

Toimittaneet Annekatrin Kaivapalu, Külvi Pruuli.

Jyväskylä Studies in Humanities, 53.

Jyväskylä: Jyväskylän yliopisto, 2006, pp. 85-101.

ISBN 951-39-2450-5

ISSN 1459-4323 


\section{Sissejuhatuseks}

Eesti keeles esineb võrreldes muude keeltega väga palju mitmesugust homonüümiat, mille on kaasa toonud ennekõike sise- ja lõpukadu ning laadivaheldusega kaasnevad häälikumuutused (Metslang 2004: 72). „Eesti keele käsiraamatu" (EKK 1997: 523-528) andmetel peetakse eesti keele homonüümidest rääkides tavaliselt silmas just sõnavormide homonüümiat ning eristatakse kahte liiki homonüümseid sõnavorme: paradigmasisesed ja paradigmavälised homonüümid, millest esimesi on eesti keeles rohkem. Ka sihitise käänete vormiline kokkulangevus kuulub paradigmasisese vormihomonüümia valdkonda, nt langevad pesa-tüüpi sõnades kokku kõik ainsuslikud sihitise käändevormid: nimetav, omastav ja osastav. Homonüümiast tingitud vormiline ebaselgus võib kaasa tuua partitiivobjekti käände markeerimise analoogialõppude abil (ainsuses $-t / d$, mitmuses -sid) ka sellistes muuttüüpides, kuhu need ei kuulu. ${ }^{1}$ Eriti sageli puutuvad objektikäände eristusvajadusele viitava liigse markeerimisega kokku koolide emakeeleõpetajad, parandades õpilaste töödes partitiivivorme *isat, *emat, *tädit jne, mis praeguse keelenormi kohaselt on ebakorrektsed. ${ }^{2}$ Mati Hint (2004: 231) toob t-lõpulise partitiivi kasutamise esile $a-, i$-, $u$-tüvelistes esmavältelistes sõnades tehtavate sagedasimate morfoloogiavigade loetelus. Riho Grünthal (2002: 27-28) seostab objekti markeerimise vajadust muu hulgas osastava käände lõpu -t/-sid produktiivsusega, mille levik oma algupärasest sõnatüübist ka teistesse sõnatüüpidesse ja sellest tulenev keelesüsteemi ühtlustava analoogia mõju on tema arvates näha selles, et tänapäeva eesti kirjakeel peab neid käändelõppe loomulikuks teatud tüüpi pärisnimedes (nt Mati) ja uutes laensõnades (nt auto). Just objekti vormihomonüümia on R. Grünthali (samas: 28) arvates üks eesti keele morfotüpoloogilisi jooni, mis on sünnitanud ilmse vajaduse selgemalt väljendada lause aspekti- ja referentsisuhteid ning mis on põhjustanud ära-tüüpi adverbide suure leviku eesti keeles. Sama seisukohta on

1 Partitiivis võivad muidugi olla muudki lauseliikmed, nt osaalus, siinses artiklis keskendutakse vormihomonüümia probleemidele sihitise seisukohast.

2 Samakujuliste käändevormide vältimiseks partitiivi märkimine formatiiviga $t$ (nt osastav munat, sabat) on omane ka lastekeelele (Argus 2004: 43). Samalaadseid vorme on oma laste keeles täheldanud ilmselt paljud vanemad, näiteks siinkirjutaja tütar kasutas kaheaastasena pesa-tüüpi sõnades regulaarselt $t$-lõpulist partitiivi (nt karut, tädit, kalat jne), kuid need on vaid tähelepanekud, mis pole uurimuses fikseeritud. 
väljendanud ka H. Metslang (1997: 32), kelle arvates on aspekti väljendamist verbipartiklite, eriti ära-partikli abil eesti keeles ühe tegurina mõjutanud just keele siseareng aglutineerivusest flekteerivuse suunas ja sellega kaasnev vormihomonüümia kasv keeles, kusjuures väljendust leiab just perfektiivne aspekt, mis on eesti keeles opositsiooni markeeritum poolus.

Konsonantlõpulise partitiivi kasutusala laienemine ja perfektiivsusadverbide kasutamine ei ole siiski ainsad võimalused, kuidas vältida objektikäänete vormilisest kokkulangevusest tulenevat mitmeti tõlgendatavust. R. Grünthal (2001: 55-58) toob sihitise vormihomonüümia süntaktilise neutraliseerimise vahenditena esile ühildumise, rinnastuse ning morfoloogilist tõlgendust piiravad süntaktilised reeglid, mis hõlmavad eituslauset, umbisikulist tegumoodi ja kvantoritarindeid. Need süntaktilised vahendid neutraliseerivad Grünthali andmetel 70-75\% juhtudel objektide vormihomonüümia (andmestik pärineb 11 000sõnalisest ajalehetekstidest kogutud materjalist, kuid ei ole öeldud, kui palju sihitisi ainestikus esines), ülejäänud juhtudest umbes pooltel on vormihomonüümia neutraliseeritud semantiliselt ning 10-15\% juhtudest jääb vormihomonüümse sihitise kääne ebaselgeks (samas: 57-58). Siinkohal tuleks aga mainida, et nimetatud süntaktilised vahendid neutraliseerivad suuremal osal juhtudest sihitise vormihomonüümia eesti keelt emakeelena kõnelejate tekstis, teise keele kõnelejate keelekasutust, sh objektikasutust ei reguleeri aga täielikult samad mehhanismid, mistõttu ei saa õppijakeele vormihomonüümseid sihitisi käsitleda emakeelekõnelejatega samadel alustel.

Sihitise vormihomonüümia põhjustab keeleuurijale raskusi eelkõige siis, kui uurimuse eesmärkidest lähtuvalt tekib vajadus tegelikus keelekasutuses esinevaid objekte käände alusel liigitada. Nimisõna kolme esimese käände vormilisest kokkulangemisest tulenevate probleemidega puutuvad kokku arvutuslingvistid seoses automaatse morfoloogilise ühestamisega, kuna formaalselt on raske määrata, miks üks ja sama sõnavorm (nt raha) peaks ühes lauses olema nt genitiivis, teises aga partitiivis (Puolakainen 2000: 82-83), ning suurim osa ühestamisel tekkinud vigu seisnebki selles, et nimisõna puhul valitakse homonüümsetest käändevormidest (nimetav, omastav, osastav või lühike sisseütlev) vale variant (Kaalep \& Vaino 2000: 97). Vormihomonüümia võib põhjustada arusaamatusi ka lause tuumargumentide eristajana juhtudel, kui lause objekt ja subjekt käändemärgistuselt ega ka ühildumise abil teineteisest ei eristu. Liina Lindströmi (2004) uurimuse andmetel eristab vormilt kokkulangevaid (nii ainsuslikke kui ka mitmuslikke) aluseid ja sihitisi eestikeelses lauses enamasti sõnajärg (subjekt on lauses enne objekti) ning kui infostruktuurilistel kaalutlustel paikneb objekt enne subjekti, aitab tuumargumente eristada semantika ehk meie üldised teadmised maailmast.

Käesolev artikkel keskendub eesti keele kui teise keele õpetajate ja uurijate tööd raskendavatele juhtumitele, mil eesti keelele omase vormihomonüümia tõttu pole võimalik õppijakeeles esinevaid sihitise käändeid üheselt interpreteerida. Vaatluse alla tulevad niisugused objektikasutusjuhud, mille puhul ka nt täiendi ühildumine, objektide rinnastamine vm süntaktilised vahendid vormihomonüümiat ei neutraliseeri ning õppijate poolt kasutatud sihitise kääne jääb ebaselgeks. Artiklis analüüsitakse vormihomonüümsete sihitiste kasutusjuhtu- 
meid eesti keelt teise keelena kõnelejate kirjalikus ja suulises eesti keeles ning tuuakse näiteid ka introspektiivse materjali hulgast. Keeleuurija vaatepunkti kõrval püütakse käsiteldavat ainestikku vaadelda ka õppija seisukohast, millest lähtuvalt võib vormihomonüümia osutuda sihitise kasutamisel hoopis toetavaks teguriks.

\section{Materjal ja meetod}

Artiklis analüüsitav keelematerjal on pärit eesti keelt teise keelena kõnelejate kirjalikku ja suulist objektikasutust käsitleva suurema uurimuse tarbeks kogutud ainestikust. Nimetatud uurimuse informantideks on Tartu Ülikooli eesti keele (võõrkeelena) eriala vene emakeelega üliõpilased, kes valdavad Eestis kasutusel oleva tasemeeksamite süsteemi järgi eesti keelt kõrgtasemel ${ }^{3}$. Kirjaliku keelekasutuse materjal on pärit informantide ülikooliõpingute lõpuosas sooritatud tänapäeva eesti keele eksami esseeosast. 28 informandi esseedest (keskmine pikkus 369 sõna) on välja kirjutatud kõik käändsõnalised objektid, kokku 581 objektikasutusjuhtu, millest 40 ei olnud vormihomonüümia tõttu võimalik sihitise käänet kindlaks määrata ning mis on seetõttu eraldi rühmaks liigitatud ning kuuluvad käesoleva artikli andmebaasi. ${ }^{4}$

Suulise keelekasutuse materjal pärineb samade informantidega läbi viidud intervjuudest, millest võttis osa 15 informanti. Igaühega on lindistatud 30-40 minutit vaba vestlust sarnastel teemadel (erialavalik, eesti keele õppimisega seonduv, tulevikuplaanid jne), lindistused on läbi viidud ja litereeritud käesoleva artikli autori poolt. Ka suulise kõne litereeringutest on välja kirjutatud kõik käändsõnaliste objektide esinemisjuhud (kokku 882 objekti), millest 31 ei olnud vormihomonüümia tõttu võimalik täpsemalt liigitada ning mis kuuluvad käesoleva artikli andmebaasi.

Introspektiivse materjali hankimiseks on 15le suulise kõne informandile intervjuude lõpus esitatud 7 eestikeelset lauset, milles tuli sihitis panna nende arvates sobivasse käändesse ning oma valikut ka põhjendada. Ka need küsitlusandmed lindistati ja litereeriti, käesolevas artiklis tulevad vaatluse alla vaid vormihomonüümiaga seotud näited. 5

Artiklis käsitletakse vormihomonüümseid sihitisi peamiselt keeleuurija seisukohast, tuues esile seesuguste juhtude liigitamisega seonduvaid probleeme, samas hoitakse taustal ka keeleõppijate võimalikku vaatepunkti. Just viimast arvestades on oluline märkida, et kirjaliku keelekasutuse materjal

3 Kõik informandid on sooritanud eesti keele kõrgtaseme eksami, mis vastab ESU (English Speaking Union) keeleoskustasemete üldskaalal tasemetele 5-8 ning Euroopa Nõukogu keeleoskustasemete üldskaalal seostatakse seda tasemega C1 (Hausenberg jt 2003: 12-18).

$4 \quad$ Vaadeldava informandirühma kirjalikus eesti keeles kasutatud kõigist objektidest saab põhjalikumalt lugeda Raili Pooli artiklist „Täis- ja osasihitis kõrgtasemel eesti keelt teise keelena kõnelejate kirjalikus keelekasutuses" (Pool 2005).

5 Kogu introspektsiooni teel kogutud materjali analüüsi vt Raili Pooli artiklist „Täis- ja osasihitise kasutamisest eesti keelt teise keelena õppijate pilgu läbi" (Pool: ilmumas). 
pärineb informantide jaoks otsustava tähtsusega eksamitöödest, milles püütakse igati vigu vältida ning rakendatakse keeleteadmisi, milles ollakse kõige kindlamad. Suulise keelekasutuse ning introspektsiooni kohta informandid hinnangulist tagasisidet ei saanud, kuid kuna lindistuste läbiviijaks oli nende õppejõud, pole ka selles materjaliosas välistatud keelelise korrektsuse taotlemise püüd. Seesuguseid taustateadmisi arvestades on tõenäoline, et informandid on rakendanud ka vältimisstrateegiaid, mille üheks avaldumisvormiks võib olla vormihomonüümsete objektnoomenite kasutamine.

Teise keele ja võõrkeele õppimise kirjeldamiseks on rakenduslingvistikas kasutusel 3 peamist viisi (James 1998: 3):

1) emakeel : sihtkeel - kontrastiivne analüüs;

2) vahekeel : sihtkeel - veaanalüüs;

3) emakeel : vahekeel - ülekandeanalüüs.

Käesolevas artiklis käsitletava uurimuse puhul on informantide emakeeleks (L1) vene, sihtkeeleks (L2) eesti keel. Vahekeeleks nimetatakse teise keele uurimisel keeleõppijate poolt kõneldavat sihtkeele varianti ning vahekeele teooria pooldajad on seisukohal, et õppijate keelekasutust (e vahekeelt) tuleks uurida selle oma vahenditega, jättes kõrvale emakeele ja sihtkeele (vt Corder 1981; Lakshmanan \& Selinker 2001 jm). Käesoleva artikli autori arvates võib aga õppijate keelevormi kirjeldamisel nende emakeelega paralleelide toomisest abi olla, samuti võib vajalikuks osutuda teise keele kõnelejate keelekasutuse võrdlemine eesti keelt emakeelena kõnelejate keelekasutusega ja eesti keele normatiivse grammatikaga. Seetõttu peab siinkirjutaja õppijakeele ${ }^{6}$ uurimisel otstarbekaimaks lähtuda Carl James`i (1994) seisukohast, mille järgi tuleks õppijate keelekasutuse analüüsimisel ära kasutada nii kontrastiivse analüüsi, veaanalüüsi kui ka ülekandeanalüüsi vahendid, kuna erinevad keelenähtused vajavad seletamiseks erinevaid lähtekohti. Käesolevas artiklis kasutatavat lähenemisviisi õppijakeelele võib seega nimetada kasutusanalüüsiks, mis teise keele kõnelejate väljundkeelt täies ulatuses arvesse võttes võimaldab laiemat käsitlust kui ainult kõrvalekaldeid käsitlev veaanalüüs. ${ }^{7}$

$6 \quad$ Kasutan keeleõppijate kõneldava keelevormi kohta nimetust õppijakeel, kuna vahekeel, mis on küll terminina rahvusvaheliselt aktsepteeritud, seostub eelpool nimetatud jäigavõitu lähenemisviisiga, mis jätab kõrvale õppijate emakeele ja sihtkeele.

$7 \quad$ Põhjalikku käsitlust õppijakeele analüüsimise erinevatest võimalustest vt Ellis \& Barkhuizen 2005. 


\section{Sihitise vormihomonüümia eesti keelt teise keelena kõneleja- te keelekasutuses}

\subsection{Kirjalik keelekasutus}

Emakeelekõnelejate kirjalikku keelekasutust analüüsides võiks keelt ise emakeelena kõnelev uurija liigitada vormihomonüümiaga objektikasutusjuhtumeid iseenda keeletajust lähtuvalt. ${ }^{8}$ Teise keele kõnelejate kirjaliku keelekasutuse puhul nii aga teha ei saa, sest nende keelelisi valikuid pole võimalik täielikult ennustada, ka väga hea keeleoskusega informandid ei pruugi kõiki keele nüansse tajuda emakeelekõnelejate moodi.

Kirjaliku keelekasutuse 40 vormihomonüümiaga näite hulgas on selliseid, mille puhul oleksid kolmest vormiliselt kokkulangevast objektikäändest kaks konkreetses lauses võimalikud. Keeleõppija seisukohast on seesugused objektnoomenid kindel valik, sest vormiliselt võib olla tegemist nii täis- kui osasihitisega, keeleuurija jaoks on aga käände määratlemine probleemiks. Näiteks:

(1) Raskused teevad tema elu ( (nom.), gen. v part.) huvitavamaks ja põnevamaks.

Genitiivi puhul oleks näites (1) tegemist perfektiivse aspektiga, partitiivi puhul imperfektiivsega. Põhimõtteliselt võiks selle näitelause objekti pidada ka nominatiivivormiks, kuna siin langevad tõepoolest vormiliselt kokku kõik kolm sihitisekäänet. Nominatiivi julgeb siinkirjutaja aga tõlgendusvõimalusena välistada, kuna näitelause produtseerinud informandi ülejäänud objektikasutuste põhjal võib öelda, et isikulise tegumoe kindla kõneviisi jaatavas kõnes oleva pöördelise verbivormi juures ta nominatiivset objekti ei kasuta (kõnealuse informandi esseest on kokku fikseeritud 33 sihitist, millest kaks ei ole eesti keele grammatika kohaselt korrektsed, kuid need mõlemad on partitiivobjektid täissihitist eeldavas kontekstis).

(2) Ma olen kindel, et tark inimene teeb tingimata karjääri (gen. v part.) ja saavutab oma elus kõike, mida ta tahab ja mille poole püüdleb.

Emakeelekõneleja kirjalikus keelekasutuses tuleks näite (2) sihitis karjääri osastavakäändeliseks analüüsida, suulises kõnes eristaks käänet välde. Teise keele kõnelejate puhul ei pruugiks näite (2) suulinegi esitus vormi analüüsimiseks kindlat tuge pakkuda. Vältevead kuuluvad Mart Rannuti (2000: 9) andmetel vene aktsendi silmatorkavamate tunnusjoonte hulka ning sarnaselt paljude eesti keele kui teise keele õpetajatega on ka on artikli autor keeleõpetajana kogenud, et õppijad ei tee sageli vahet teisel ja kolmandal vältel, kasutades sel-

$8 \quad$ Nt Valter Tauli (1968) on liigitanud 2252 eesti ilukirjandusest kogutud objekti totaal(644 e $28,6 \%$ ) ja partitiivobjektideks (1 608 e 71,4\% juhtudest), vormihomonüümseid sihitisi eraldi nimetamata, kuigi selliseid nii suure materjali hulgas kindlasti esineb (näidete seaski on mõned ära toodud), järelikult ei olnud vormihomonüümia objektide liigitamisel probleemiks. 
gelt eristamatut vahepealset häälikupikkust. ${ }^{9}$ Seega ei ole informanti küsitlemata võimalik kindlalt väita, kas ta on silmas pidanud sihtkeelepärast partitiivivormi (taustaks võib siin olla ka asjaolu, et vene keele objektikääne akusatiiv üldistatakse sageli eesti partitiivina) või on soovinud moodustada resultatiivset konstruktsiooni täissihitise abil. Kirjaliku keelekasutuse ainestikus esines kokku 42 ilma vormihomonüümiata genitiivset täissihitist, millest 9 ehk 21,4\% oli kasutatud partitiivobjekti (või paralleelselt nominatiiv- või partitiivobjekti) eeldavas kontekstis, nt Öeldust järeldub, et ülikool andis mulle eelkõige suhtlemisoskuse ja tõstis mu enesehinnangu (pro enesehinnangut), mis annab põhjust järelduseks, et ka näite (2) interpreteerimisel ei saa genitiivivormi välistada ning emakeelekõneleja keeletajust lähtuv objektikäände liigitamine ei pruugi anda tõeseid tulemusi, mistõttu seesugused kaheti tõlgendatavad juhtumid on põhjust koondada eraldi rühma.

Genitiiv ja partitiiv langevad kirjapildis kokku ka järgnevates näidetes:

(3) Mina lähen turismibüroosse, tellin endale reisi (gen. v part.) Hispaaniasse...

(4) Ülikool aitas mul laiendada oma silmaringi (gen. v part.).

(5) Sel aastal kavatsen ma lõpetada ülikooli (gen. v part.).

Kui samad laused oleks produtseerinud emakeelekõneleja, võiks näidetes (3) ja (5) määrata genitiivivormilise täissihitise, lauses (4) osasihitise partitiivis, teise keele kõnelejate puhul ei saa midagi kindlalt otsustada. Oma osa mängib siinjuures $\mathrm{ka}$ asjaolu, et informantideks on eesti keele eriala üliõpilased, kes on saanud lisaks praktilisele keeleõpetusele ka teoreetilise eesti keele alase ettevalmistuse, mistõttu sihtkeele reeglitest lähtumise soov võib olla sama tugev objektikasutust mõjutav faktor kui alateadlik emakeele mõju. Eesti keele kui sihtkeele seisukohast on lauses (4) tegemist kinnisväljendiga silmaringi laiendama, milles on kinnistunud nimelt partitiivobjekt, kuigi laiendama-verb iseenesest võimaldab resultatiivsetes konstruktsioonides ka täissihitise kasutamist, vrd H. Rätsepa verbikesksetes lausemallides toodud näitelause Kirurg laiendas avause kolmanda roideni (Rätsep 1978: 176). Näites (5) esineb sisult perfektiivne lopetama-verb ning ka lause tervikuna on perfektiivse tähendusega. Näidete (3)(5) mitmeti tõlgendatavust toetavad kirjaliku keelekasutuse ilma vormihomonüümiata sihitiste liigituse andmed. Genitiivobjektide kasutamist partitiivi eeldavates kontekstides on juba mainitud seoses näitega (2), kuid samamoodi tuleb esile partitiivse sihitise tarvitamine seal, kus emakeelekõneleja keeletaju ootaks totaalobjekti: 378-st ilma vormihomonüümiata partitiivobjektist 40 ehk $10,6 \%$ pidanuks sihtkeelepäraselt olema genitiivis (või nominatiivis), nt See mees unustas oma perekonda (pro perekonna), mis jäi kodumaale. Seesuguse ulatuslikuma materjali olemasolu toetab seisukohta, et vormihomonüümiaga sihitiste liigitamine emakeelekõneleja keeletaju järgi pole õigustatud ning neid tuleks mitmeti tõlgendatavuse tõttu eraldi käsitleda.

$9 \quad$ Vene aktsendist eesti keeles on valminud Lya Meisteri magistriväitekiri (Meister 2005). 
Juhtumeid, mille puhul langevad kokku nominatiivi ja genitiivi vormid, kusjuures genitiivi kasutamine on grammatiliselt korrektne, illustreerib näide (6):

(6) Aga juhtus nii, et ta kaotas töö ((nom.) v gen.) ära.

Kogu kirjaliku keelekasutuse materjali arvestades võib väita, et vaadeldav informandirühm ei tee praktiliselt objektivigu, mille puhul genitiivi asemel oleks tarvitatud nominatiivi ning et perfektiivsusadverbiga ära seostatakse peamiselt genitiivobjekti (põhjalikumalt vt Pool 2005). Näites (6) on küll objekt teoreetiliselt võimalik analüüsida nii nominatiiviks kui genitiiviks, lause produtseerinud informandi kõiki ülejäänud sihitisekasutusi arvesse võttes võib aga üsna kindel olla, et silmas on peetud omastavat käänet, kuna tema keelekasutuse ainestikus puuduvad näited, milles oleks kindla kõneviisi isikulise tegumoe korral tarvitatud mittesihtkeelepärast ainsuslikku nominatiivobjekti (kõnealuse informandi esseest on selles positsioonis fikseeritud 2 genitiiv- ja 11 partitiivobjekti). Niisugused järeldused on võimalikud seetõttu, et siinkirjutaja käsutuses on samalt informandilt ulatuslikum keelematerjal ning näide (6) on eelnevat arvestades arvatud genitiivsete, mitte vormihomonüümsete objektide hulka. Käesoleva uurimuse informantide kirjalikus keelekasutuses kirjeldatud positsioonis ainsuslike nominatiivobjektide puudumine ei tähenda aga seda, et kõigi teise keele kõnelejate sihitisekasutust reguleeriksid samad seaduspärasused ning et kõik keeleõppijad seostaksid ära-adverbi genitiivobjektiga. Viktoria Orlova toob oma objektivigade alases Tartu ülikooli bakalaureusetöös esile ka näiteid, milles on genitiivi asemel tarvitatud nominatiivi, sealhulgas ka ühendis ära-adverbiga, nt Isa võttis pinali ja pesi see (pro selle) ära ja see näis olevat uus (Orlova 2003: 94). Erinevused siinse uurimuse materjali ja V. Orlova ainestiku vahel tulenevad tõenäoliselt sellest, et V. Orlova infomantideks olid eesti keelt kesktasemel10 valdavad üliõpilased, käesolevas artiklis aga kasutatakse andmeid, mis on kogutud kõrgtasemel eesti keele kõnelejatelt, kelle grammatikateadmised on juba põhjalikumad. Kokkulangevate nominatiivi- ja genitiivivormide puhul ei saa seega ainult üksikute näidete olemasolul nominatiivobjekti kasutussoovi välistada, järelduste tegemiseks on vajalik samadelt informantidelt suurema keelematerjali olemasolu.

Näide (6) on huvitav seetõttu, et kas resultatiivsuse rõhutamiseks või mõnel muul põhjusel on lausesse lisatud ka perfektiivsusadverb ära. Tegemist võib olla ka sihtkeele tundmisest lähtuva liigse üldistamisega, on ju ärapartikkel väga tavaline perfektiivsuse väljendamise vahend eesti keeles (vt Metslang 1997, 2001) ning sobib kindlasti kasutamiseks ka kaotama-verbiga, nt kaotasin rahakoti ära, kuigi resultatiivsust väljendab sel juhul ka täissihitis üksi ning eriti kirjutatud keeles loetakse ainult piiritletust väljendavaid abimäärsõnu sageli liiasteks (vt EKG II: 51, Rajandi \& Metslang 1979: 36; Uuspõld 1997: 745).

10 Vaadeldavad informandid on sooritanud eesti keele kesktaseme eksami, mis ESU keeleoskustasemete üldskaalal vastab tasemetele 3-5 ning mida Euroopa Nõukogu keeleoskustasemete süsteemi üldskaalal seostatakse tasemega B2 (Hausenberg jt 2003: 12-18). 
Näites (6) kasutatud objektnoomen töö kuulub kvantifitseeritavuse järgi nn ainesõnade hulka (EKG II: 141), mis kaotama-verbi laiendades ära-adverbi ei salli (sarnaselt näitega (6) ei võimalda eesti keel ära-adverbi lisamist veel mitmete sihitise funktsioonis kasutatud ainesõnadega, nt kaotasin meelekindluse/huvi/julguse jm, nn asjasõna puhul olnuks näites (6) tarvitatud konstruktsioon eesti keeles loomulik, nt kaotasin võtme/kinda/passi ära, kusjuures viimatinimetatud juhtudel võib ära pidada fakultatiivseks). Objektnoomeni semantikat tuleb keeleõppijatel seega arvestada mitte ainult objektikäände valikul, vaid ka perfektiivsete adverbide kasutamisel. Lauses (6) ei saa ära-partikli liigtarvitust seostada vajadusega eristada perfektiivset aspekti imperfektiivsest, kuna imperfektiivsuse väljendamiseks vajalik partitiivivorm tööd ei lange genitiivivormiga töö kokku. Objektnoomeni totaalse ja partsiaalse vormi homonüümsuse korral osutub ära ainsaks vahendiks aspekti ühemõtteliselt märkida, vrd keetis kana (imperfektiivne? perfektiivne?) - keetis kana ära (perfektiivne) (Metslang 1997: 39).

Vormihomonüümiaga objektide hulgas on ka juhtumeid, kus kokku langevad nominatiivi ja genitiivi vormid, kuid need kumbki pole konkreetses lauses aktsepteeritavad, kuna vaja oleks hoopis osasihitist, näiteks:

(7) Ta annab ka alati hea nõu ((nom.) v gen.) ja aitab sõpra hädas.

Kuigi näitelause (7) moodustanud informandi objektikasutust analüüsides võib nominatiivi siin välistada (samalt informandilt pärineb ka näide (1), mida on eespool analüüsitud), ei ole ka genitiiv emakeelekõneleja keeletaju jaoks täielikult aktsepteeritav, kuna püsiühend nõu andma on kinnistunud partitiivse sihitisega ning emakeelekõneleja moodustatuna oleks objektnoomeni nõu vormihomonüümia sellel juhtumil olnud adjektiivatribuudi ühildumise kaudu neutraliseeritud (partitiivivorm head on üheselt tõlgendatav). Võimalik, et lause (7) autor ongi soovinud kasutada partitiivobjekti, kuid eksinud vormimoodustuses.

Hüpoteesina võib esitada küsimuse, kas mõnel juhul oleks võimalik vormihomonüümiaga objektnoomeni kasutust pidada vältimisstrateegia avaldumisvormiks. Kuna informandid on filoloogiaüliõpilased ning tunnevad eesti keele struktuuri, võiks vähemalt teoreetiliselt tulla kõne alla võimalus, et kirjalikus tekstis valitakse mõnikord objektiks nimelt kokkulangevate objektikäänetega noomen, sest siis pole karta eksimist. Tuleb arvestada, et materjal on kogutud informantide jaoks otsustava tähtsusega eksamitöödest, mille kirjutamisel püütakse igati vigu vältida. Loomulikult sõltub niisugune võimalik vältimisstrateegia rakendamine väga tugevasti informantide individuaalsetest iseärasustest, kuid et päris võimatu selline oletus pole, annavad tunnistust ka artikli autori informaalsed vestlused üliõpilastega. Keeleõppijate vältimisstrateegiate empiiriliseks uurimiseks tuleks õppijakeele ainest võrrelda emakeelekõnelejate samalaadsest materjalist kogutud andmetega, seesugune võrdlus ei mahu aga selle artikli raamidesse. 


\subsection{Suuline keelekasutus}

Ka suulise kõne materjali hulgas leidunud 31 vormihomonüümiaga sihitise hulgas oli selliseid, mille puhul langevad kokku kõik kolm ainsuslikku sihitise käänet - nominatiiv, genitiiv ja partitiiv, kuid informantide suulises ja ka kirjalikus kõnes esinenud muid objekte arvestades võib sihtkeele seisukohast ebagrammatilise nominatiivivormi konkreetsetes lausungites välistada. Näiteks:

(8) ja isa võttis siis minu ema ((nom.), gen. v part.) naiseks

(9) ja seal me saime teeraha ((nom.), gen. v part.) või

Näites (8) tuleks sihitis emakeelekõnelejate keeles genitiivivormiliseks analüüsida, kuna nii tegevus kui ka objektiese ise on piiritletud (vt EKG II 1993: 51). Õppijakeele kohta ei saa aga kindlat seisukohta võtta, sest kuigi näite produtseerinud informandil on suurepärane eesti keele oskus, tuleb tema keelekasutuses aeg-ajalt siiski ette partitiivobjekti liigtarvitamist (nt täissihitist eeldavas kontekstis: ta loppetas seda (.) ôhtukooli) ning ka vaadeldaval informandirühmal tervikuna esineb partitiivobjekti kasutamist täissihititise asemel sarnaselt kirjaliku keelekasutusega samamoodi ka suulise materjali hulgas (532-st suulisest ainestikust kogutud ilma vormihomonüümiata partitiivobjektist 19 ehk 3,4\% pidanuks sihtkeele seisukohast olema genitiivis või nominatiivis), mistõttu on toodud näite liigitamine vormihomonüümiaga objektide erandrühma põhjendatud. Näite (9) sihitis teeraha võiks sihtkeele seisukohast olla niihästi genitiivis kui ka partitiivis, vastavalt sellele, kas objektieset käsitada kvantitatiivselt piiritletuna või mitte, ka õppijakeeles ei ole objektikääne üheselt määratletav. pesatüüpi sõnad (nagu kahes viimases näites ema, raha jms) on keeleõppijatele sihitisena kasutamiseks kõige lihtsamad, kuna eesti keele morfoloogia eripära tõttu puudub formaalselt eksimisvõimalus käände valikul, tuleb vaid selgeks õppida, et kolm esimest ainsuse käändevormi neis sõnades on identsed.

Kahes järgnevas näites on samuti tegemist pesa-tüüpi kuuluvate objektnoomenitega, kuid lausungite süntaktilise struktuuri tõttu ei saa neis ühtegi käändevormi vaadeldava informandirühma keeles välistada.

(10) kõige raskem oli (.) õppekava (nom., gen. v part.) koostada

(11) kui minu peamine eesmärk on teenida raha (nom., gen. v part.) korteri jaoks

Nii näites (10) kui ka (11) laiendavad sihitised da-infinitiivi, mis näites (10) talitleb subjektina, lauses (11) aga predikatiivina ning mille juurde saab kuuluda üksnes nominatiivne täissihitis, genitiiv objektikäändena on neis struktuurides eesti keele seisukohast välistatud, osasihitis partitiivis on paralleelvariandina muidugi võimalik. Teise keele kõnelejate jaoks on aga da-infinitiivi laiendavad marginaalsed nominatiivobjektid võõrad, kuna neil on suured esinemispiirangud, mis nõuavad ka lauseanalüüsi oskust. Samadelt informantidelt kogutud introspektiivne materjal näitab, et resultatiivsuse väljendamiseks eelistavad nad ka subjektina ning atribuudina talitleva da-infinitiivi objektina tarvitada sihtkeele seisukohast ebagrammatilist genitiivivormis täissihitist (Pool: il- 
mumas). Eelnevat arvestades on näidete (10) ja (11) autorid tõenäoliselt pidanud silmas kas genitiivset täissihitist või siis partitiivset osasihitist, täpsem määratlemine on siinjuures keeleuurija probleemiks, õppija jaoks muudab vormihomonüümia niisuguste harvaesinevate konstruktsioonide kasutamise kindlamaks. ${ }^{11}$

(12) pidime teist korda minema ja küsisime et (...) äkki saaksite sama laulu (gen. v part.) laulda jälle et palume vabandust

(13) seminaritööks ma uurisin neid e:: keelekümbluslapsi (...) et e:: (...) andsin nendele testi (gen. v part.)

(14) no vot tema saatis mulle nende projektide juhtide nimekirja (gen. $v$ part.)

Näidetes (12)-(14) langevad eesti keeles genitiiv ja partitiiv kokku vaid kirjapildis, emakeelekõnelejate suulises kõnes on käände eristajaks välde, kõigi kolme näite objektnoomenid on genitiivis teises, partitiivis aga kolmandas vältes. Samas ei olnud teise keele kõnelejatest informantide suulise kõne lindistuste järgi võimalik aru saada, millise vältega oli tegu ning isegi kui välde oleks olnud selgelt eristatav, ei pruugi see olla kindel kriteerium käände määratlemiseks, kuna keeleõppijate teadmised väldete ja käändevormide seoste kohta võivad olla ebapiisavad. Niisugustel juhtudel on abiks informantide küsitlemisel saadud andmed, käesoleva uurimuse informante intervjuu käigus keelekasutuse asjus ei küsitletud, et mitte rikkuda lindistuse sundimatut õhkkonda. Informantide küsitlemist on eesti keele kui teise keele alastes uurimustes ka kasutatud. Näiteks Olga Pastuhhova toob oma vene üliõpilaste interferentsivigu käsitlevas uurimuses välja küsitlemise teel saadud andmed, mis annavad tunnistust selle kohta, et suulises kõnes lause Mina lõpetasin $\underline{k u t-}$ sekõrgkooli (gen. v part.) produtseerinud informandil, kes hääldas objekti sihtkeelepäraselt teises vältes, ei ole tegelikult aimugi sellest, mis on eesti keeles välde ja ta ei tee nende vahel mingit vahet (Pastuhhova 2005: 93-94). Seega võib sihtkeelepärane hääldus olla vaid juhuslik ning selle abil käände määratlemine võib anda ebatõeseid tulemusi. Suulise keelekasutuse ilma vormihomonüümiata objektikasutust arvestades (partitiivobjekte oli kokku 532, neist 19 sihtkeele seisukohast ebakorrektset, genitiivobjekte 91, neist 4 viga) on näited (12)-(14) tõlgendatavad nii genitiivi- kui ka partitiivivormilisena. Eelnevat arvesse võttes on seega ka suulise kõne materjali hulgas esinenud vormihomonüümiaga sihitised mõttekas liigitada eraldi rühma.

\subsection{Introspektiivne materjal}

Introspektiivsete meetodite rakendamisel kogutakse empiiriline materjal informantide suulise küsitlemise teel, eeldades, et keeleõppijad suudavad ise jälgida

11 Tahaksin siinkohal tänada artikli anonüümset retsensenti, kes on täpsustanud näidete (10) ja (11) interpretatsiooni järgmiselt: mõlemas lauses kirjeldatav situatsioon on imperfektiivne, neist esimese puhul räägitakse kõnemomendiks lõppenud protsessist ja teises - kõnemomendile järgnevast protsessist, ehk esimene on minevikuline protsessuaalsus (teatud aja kestnud pidev tegevus) ja teine - tulevikku suunatud eesmärgipärane ajaliselt kestuselt määratlemata (piiritlemata) tegevus. 
ja kirjeldada mentaalseid protsesse, mis juhivad nende keelelisi tegevusi. Keeleõppijate endi arvamused keeleomandamisega seonduvate küsimuste kohta annavad väärtuslikku informatsiooni keeleõpetamise metoodika täiustamiseks ning õppetöö paremaks planeerimiseks. Keeleõpetajad arvavad enamasti teadvat, kuidas nende ópilased õpivad ja keelelisi valikuid teevad, keeleõppijate endi seletused ei pruugi aga alati õpetajate arvamustega kokku langeda. Käesolevas artiklis käsitletav õppijakeele aines on pärit filoloogiaüliõpilastest informantidelt, kes suudavad oma keelelise käitumise kirjeldamisel ära kasutada ka enda teoreetilised teadmised sihtkeelest. Suurema uurimuse tarbeks lindistatud introspektiivne materjal koosneb seitsmest eestikeelsest lausest, milles informandid põhjendasid enda arvates sobiliku objektikäände kasutamist ${ }^{12}$, siinses kirjutises tulevad vaatluse alla vaid vormihomonüümiaga seotud näited. Ühesse informantidele arutluseks esitatud lausetest oli valitud vormihomonüümiaga objektnoomen:

(15) Laeva väljumiseni on vähe aega, nii et me võtame bussijaamast (takso). ja sõidame sadamasse.

Näites (15) sisalduva objektnoomeni takso (homonüümsed on nominatiivi ja genitiivi vormid) uurimusse kaasamise taustaks on eeldus, et vaadeldav informandirühm on omandanud reegli, mille kohaselt isikulise tegumoe kindla kõneviisi jaatavas kõnes pöördelise verbivormi laiendina ainsuse nominatiivis objekti ei kasutata (vt Pool 2005). Kuna vormihomonüümiaga objektide puhul ei saa midagi täie kindlusega väita, võimaldavad just introspektiivsed andmed informantide tegelikus käändevalikus selgust saada. 15st informandist üks pidas toodud lausesse sobivaks nominatiivset täissihitist takso, 10 informanti genitiivset objekti takso, mille põhjenduseks toodud tegevuse lõpetatus ja objekti piiritletus annavad tunnistust metalingvistiliste teadmiste ja produktiivse keelekasutuse kooskõlast. Näiteks: 13

(16) INF D: võtame bussijaamast takso

R.P.: mis käändes see takso siin on?

INF D: genitiivis

R:P.: mhmh (.) ja mille järgi sa valiksid selle käände?

INF D: võtame mille (.) lõpetatud tegevus (.) piiritletud objekt

4 informanti pakkusid partitiivobjekti taksot, põhjendusena esitati lausega väljendatud tegevuse toimumist praegusel hetkel, toetumist emakeelele (ühe informandi arvates oleks lause venekeelses vastes imperfektiivne aspekt, mille eesti vastena on ta enda keeleteadmistes kinnistanud partitiivobjekti, eksides tegelikult nii vene kui ka eesti keeles, kuna vene keeles on tegemist perfektiivse aspektiga, millega paralleelide toomine võinuks viia sihtkeelepärase genitiivivormini) ning võtame mida-mudeli väljakujunemist, mis sisuliselt tähendab võt$m a$-verbi arvamist partitiivverbide hulka.

12 Ülevaadet kogu introspektiivsest materjalist vt Pool: ilmumas.

13 Introspektiivse materjali litereeringutes on informandid tähistatud lühenditega INF

A, INF B jne, lühend R.P. tähistab käesoleva artikli autorit. 
Vormihomonüümiaga seotud problemaatika seisukohast andsid huvipakkuvaid tulemusi ka näites (17) esitatud lause objektikasutuse kohta antud selgitused.

(17) Ühe väikse vea pärast ei pea (terve töö). ümber tegema.

Vaid üks 15st informandist pidas näites (17) toodud lausesse sobilikuks täissihitist, jättes samas käändevormi täpsustamata:

(18) INF N: terve näitab et kogu töö (.) partitiiviga oleks ainult osa tööst

Kuna nimisõnafraasis terve töö langevad nominatiiv ja genitiiv vormiliselt kok$\mathrm{ku}$, ei saa kindlalt väita, kumba täissihitise käänet on vastaja silmas pidanud. Tõenäoliselt on informant jätnud lihtsalt tähele panemata, et tegemist oli partitiivobjekti eeldava eitava lausega ning soovinud kasutada genitiivi kui täissihitise põhikäänet. Lähtudes S. Pit Corderi (1981: 5-13) seisukohast keeleõppija vigade ja eksimuste olemusliku erinevuse kohta, tuleks informandi $\mathrm{N}$ valikut kindlasti pidada eksimuseks, kuna käesoleva artikli autori käsutuses olevates materjalides (vaba vestluse litereering ning vabad kirjutised) esinevad sama informandi keelekasutuses eitavates konstruktsioonides ainult sihtkeelepärased partitiivobjektid (suulise kõne materjalis vastavalt 10 ja kirjandis 2 eitavat verbi laiendavat osastavalist sihitist).

Ülejäänud 14 informanti pidasid näites (17) toodud lausesse sobivaks osasihitist, kusjuures objektivaliku selgitustes avaldub positiivselt keeleõpetuse mõju: kõik 14 informanti valivad osastava käände põhjendusega, et eitus nõuab partitiivis objekti, vastav reegel (lihtsaim, mis objektikasutust reguleerib) on keeletundides omandatud. Sama lause puhul avaldub ka informantide teoreetiliste teadmiste ja nende praktikas rakendamise oskuse ebakõla, nimelt ei osanud mitu informanti tegelikult antud nimisõnafraasist terve töö partitiivivormi moodustada, jättes selle algvormi terve töö (vormihomonüümia tõttu võib seda vormi pidada nii nominatiiviks kui ka genitiiviks), kuid teadsid samas, et selles lauses peab olema partitiivne sihitis. Niisugused juhtumid, mille puhul informant on jätnud sulgudes esitatud nimisõnafraasi muutmata, kuid on ise kirjeldanud seda vormi partitiivsena, on arvatud partitiivobjektide hulka. Näiteks:

(19) INF G: ei pea terve töö ümber tegema

R.P.: siin jääb siis?

INF G: terve töö

R.P.: mis küsimus see siis on?

INF G: ei pea mida tegema (.) terve töö ümber tegema (...) osastavas

Kirjeldatud asjaolu näitab, et pelgalt kirjaliku keelekasutuse analüüsimisel ei saa keeleuurija täie kindlusega otsustada, mida õppijad tegelikult on silmas pidanud, sest viimased võivad oma arust kasutada sihtkeelepärast keelendit, mis samas vormiliselt siiski seda ei ole. 


\section{Lõpetuseks}

Kuna teise keele kõnelejate keelelised valikud on sageli prognoosimatud ning õppijakeele analüüsimisel pole võimalik lähtuda samadest kriteeriumidest, millest emakeelekõnelejate keelekasutuse puhul, on täis- ja osasihitise alastes uurimustes otstarbekas mitmeti liigitatavaid vormihomonüümiaga sihitisi käsitleda eraldi rühmana, seda nii kirjalikust kui ka suulisest keelest kogutud ainestiku puhul. Kahe või ka kolme vormiliselt kokkulangeva objektikäändega noomenite puhul pole enamasti võimalik vigu kindlalt määratleda, seetõttu ei sobi niisuguste näidete analüüsimiseks ainult veaanalüüsi meetod, vaid on mõttekas rakendada laiemaid võimalusi pakkuvat kasutusanalüüsi, mis võimaldab lisaks sihtkeele seisukohast kõrvalekaldelistele juhtudele võtta arvesse ka õppijate korrektset keelekasutust (või homonüümsete vormide korral arvestada ka korrektse vormikasutuse võimalusega). Introspektiivse materjali kaasamine teise keele uurimisse aitab keeleõpetajatel ja -uurijatel õppijakeeles ilmnevaid nähtusi täpsemalt seletada ning kinnitab, et õppijakeele (käesoleval juhul konkreetselt täis- ja osasihitise kasutamise) analüüsimine emakeelekõneleja seisukohast ei pruugi anda tõest pilti teise keele kõneleja tegelikest valikutest ja teadmistest.

Artiklis käsitletud õppijakeele ainest arvestades võib eesti keele kui teise keele alaste õppematerjalide koostajatel soovitada täis- ja osasihitise harjutustesse valida ilma vormihomonüümiata objektnoomenid või kasutada nimisõnafraase, milles sihitise vormihomonüümia on täiendi ühildumise abil neutraliseeritud.

Eesti keelele omane vormihomonüümia sihitise käänetes on keeleõppijatele omamoodi tugi, välistades või minimeerides tegelikult formaalselt eksimisvõimaluse mõnedesse muuttüüpidesse kuuluvate objektnoomenite käände valikul. Eesti keele vormimoodustuse omapärast teadlike ning vabas keelekasutuses korrektsust taotlevate keeleõppijate jaoks võib vormihomonüümiaga objektide tarvitamine olla ka vältimisstrateegia avaldumisvormiks. 


\section{KIRJANDUS}

Argus, R. 2004. Eesti keele käändesüsteemi omandamine: esimestest sõnadest miniparadigmadeni. Teoses Erelt, M. \& Sepper, M.-M. (toim.) Emakeele Seltsi Aastaraamat 49 (2003). Tallinn, 23-49.

Corder, S. P. 1981. Error Analysis and Interlanguage. Oxford: Oxford University Press.

Corder, S. P. 1981. The significance of learners`errors. Teoses Error Analysis and Interlanguage. Oxford: Oxford University Press, 5-13. [Reprinted from International Review of Applied Linguistics 1967, Vol. 5, No. 4, 161170.]

EKG II = Erelt, M., Kasik, R., Metslang, H., Rajandi, H., Ross, K. , Saari, H., Tael, K. \& Vare, S. 1993. Eesti keele grammatika II. Süntaks. Lisa: Kiri. Eesti Teaduste Akadeemia Keele ja Kirjanduse Instituut.

EKK = Erelt, M., Erelt, T. \& Ross, K. 1997. Eesti keele käsiraamat. Tallinn: Eesti Keele Sihtasutus.

Ellis, R. \& Barkhuizen, G. 2005. Analysing Learner Language. Oxford University Press.

Grünthal, R. 2001. Homonymy and systemacy in Estonian inflection. Teoses Kasik, R. (toim.) Keele kannul. Pühendusteos Mati Erelti 60. sünnipäevaks. Tartu Ülikooli eesti keele õppetooli toimetised 17. Tartu, 42-61.

Grünthal, R. 2002. Vormihomonüümia ja muutuv keel. Teoses Kasik, R. (toim.) Lähivertailuja 12. Soome-eesti kontrastiivseminar 30.5-1.6.2001 Kääriku Tartu Ülikooli eesti keele õppetooli toimetised 19. Tartu, 21-34.

Hausenberg jt = Hausenberg, A.-R., Kikerpill, T., Rõigas, M. \& Türk, Ü. 2003. Keeleoskuse mõõtmine. Käsiraamat. Tallinn: TEA Kirjastus.

Hint, M. 2004. Eesti keele foneetika ja morfoloogia. Süvaõpik. Tallinn: Avita. James, C. 1994. Don't shoot my dodo: on the resilience of contrastive and error analysis. IRAL: International Review of Applied Linguistics in Language Teaching, Vol. 32 Issue 3, 179-201.

James, C. 1998. Errors in Language Learning and Use. Exploring Error Analysis. London - New York: Longman.

Kaalep, H.-J. \& Vaino, T. 2000. Teksti täielik morfoloogiline analüüs lingvisti töövahendite komplektis. Arvutuslingvistikalt inimesele. Teoses Hennoste, T.(toim.) Tartu Ülikooli üldkeeleteaduse õppetooli toimetised 1. Tartu: Tartu Ülikooli Kirjastus, 87-99.

Lakshmanan, U. \& Selinker, L. 2001. Analysing interlanguage: how do we know what learners know? Second Language Research 17, 4, 393-420.

Lindström, Liina 2004. Sõnajärg lause tuumargumentide eristajana eesti keeles.

Teoses Lindström, L. (toim.) Lauseliikmeist eesti keeles. Tartu Ülikooli eesti keele õppetooli preprindid 1. Tartu, 40-49.

Meister, L. 2005. Vene aktsent eesti keeles. Akustiline analüüs. Magistriväitekiri Tallinna Ülikoolis. 
Metslang, H. 1997. Eesti prefiksaaladverbist ära soome keele taustal. Teoses Grünthal, R. \& Kasik, R. (toim.) Lähivertailuja 9. Suomalais-virolainen kontrastiiviseminaari 3.-5.5.1996 Lammi. Castrenianumin toimitteita 53. Helsinki, 31-46.

Metslang, H. 2001. On the development of the Estonian aspect. Teoses Dahl, Ö. \& Koptjevskaja-Tamm., M. (toim.) The Circum-Baltic Languages. Typology and Contact. Volume 2: Grammar and Typology. Amsterdam/Philadelphia: John Benjamin Publishing Company, 443-479.

Metslang, H. 2004. Eesti keele keerukohti. Teoses Sulkala, H. \& Laanekask, H. (toim.) Virsu II. Viro ja suomi kohdekielinä. Lähivertailuja 15. Oulun yliopisto, suomen ja saamen kielen ja logopedian laitoksen julkaisuja N:o 24. Oulu, 71-82.

Orlova, V. 2003. Vene rahvusest üliõpilaste eesti keele objektivigade analüüs. Bakalaureusetöö Tartu ülikooli eesti keele (võõrkeelena) õppetoolis.

Pastuhhova, O. 2005. Interferentsivead vene üliõpilaste suulise ja kirjaliku eesti keele süntaksis. Teoses Pool, R. (toim.) Teine keel. Uurimusi eesti keele kui teise keele omandamisest. Tartu Ülikooli eesti keele (võõrkeelena) õppetooli toimetised 5. Tartu: Tartu Ülikooli Kirjastus, 75-110.

Pool, R. 2005. Täis- ja osasihitis kõrgtasemel eesti keelt teise keelena kõnelejate kirjalikus keelekasutuses. Teoses Pool, R. (toim.) Teine keel. Uurimusi eesti keele kui teise keele omandamisest. Tartu Ülikooli eesti keele (võõrkeelena) õppetooli toimetised 5. Tartu: Tartu Ülikooli Kirjastus, 8-74.

Pool, R. (ilmumas). Täis- ja osasihitise kasutamisest eesti keelt teise keelena õppijate pilgu läbi. Artikkel ilmumas teoses Metslang, H. \& Langemets, M. Eesti Rakenduslingvistika Ühingu aastaraamat 2 (2005).

Puolakainen, T. 2000. Eesti keele reeglipõhise morfoloogilise ühestamise probleemseid kohti. Teoses Hennoste, T. (toim.) Arvutuslingvistikalt inimesele. Toim Tiit Hennoste. Tartu Ülikooli üldkeeleteaduse oppetooli toimetised 1. Tartu: Tartu Ülikooli Kirjastus, 73-85.

Rajandi, H. \& Metslang, H. 1979. Määramata ja määratud objekt. Tallinn: Valgus.

Rannut, M. 2000. Vene aktsendist eesti keeles. Teoses Türk, Ü. (toim.) Abiks õpetajale. Eesti keele kui teise keele õpetamine. Artiklite kogumik I. EV Haridusministeerium. Tallinn, 7-17.

Rätsep, H. 1978. Eesti keele lihtlausete tüübid. Tallinn: Valgus.

Tauli, V. 1968. Totaalobjekt eesti kirjakeeles. Suomalais-ugrilaisen seuran toimituksia 145. Helsinki: Suomalais-ugrilainen seura, 216-223.

Uuspõld, E. 1997. Mõningaist liiasusnähtustest eesti keelekasutuses. Keel ja Kirjandus 11, 743-747. 